\title{
Building knowledge from the margins: information, knowledge and social movements
}

\author{
Construir conhecimento partindo das margens: \\ informação, conhecimento e movimentos sociais
}

Víctor Manuel MARÍ SÁEZ1

\begin{abstract}
The social theory that has been constructed in Latin America in the past twenty years, proposes an alternative to the traditional criteria of science boundaries. This alternative approach, oriented towards social emancipation, is gaining ground over the predominant tendency, which is to subsume knowledge into an intensive process of commoditization. Anti-globalist movements are amongst the social players that have a leading role in the development of new ways of building knowledge. These movements act based on a new relationship between processes of social change, knowledge-building and the meaning and direction of communication. In this context, communication and information cease to be instruments for the regulation and control of social behavior. The tensions arising from the market and the predominating, inherited communication models go against research concerned with building meanings and viewpoints that are alternatives to the predominant ones. The new, emerging approaches tend to strengthen bidirectional relationships between communication and social transformation.
\end{abstract}

Keywords: Alternative communication. Anti-globalist movements. Knowledge-building. Social transformation.

\section{Resumo}

A teoria social que vem sendo construída na América Latina nos últimos vinte anos propõe uma alternativa aos critérios tradicionais de demarcação das ciências. Frente à tendência dominante, que tende a subsumiro conhecimento num processo intensivo de mercantilização, abre-se passo um enfoque alternativo do conhecimento, orientado neste caso à emancipação social. Neste processo, os movimentos sociais altermundialistas são um dos atores sociais que protagonizam os novos modos de construção de saberes. Eles trabalham partindo de uma nova relação entre os processos sociais de mudança, a construção do conhecimento e o sentido da comunicação. Neste contexto, a comunicação e a informação deixam de ser instrumentos para a regulação e o controle do comportamento social. As tensões procedentes do mercado e os modelos comunicativos dominantes herdados do passado pressionam em direção contrária às pesquisas preocupadas em construir conhecimento e comunicação partindo das margens. Os novos enfoques emergentes tendem a fortalecer as relações bidirecionais entre comunicação e transformação social.

Palavras-chave: Comunicação alternativa. Movimentos sociais altermundialistas. Construção de conhecimento. Transformação social.

\section{Introduction}

Historically, scientific knowledge has been built through demarcation, the act of setting boundaries or 
order but the one authorized by power" (García Gutiérrez, 2007, p.35). As a response to the dominant classifying movement, the social theory that has been built up in Latin America in the past twenty years (Fals Borda, 1991; Quijano, 2000; Dussel, 2001; Sodré, 2002; Mignolo, 2003; Sousa Santos, 2003, 2005) poses an alternative to the traditional criteria for the demarcation of the sciences. Paraphrasing Sousa Santos (2009), this is a form of knowledge useful for emancipation rather than for the regulation of social order.

The cycle of social mobilizations towards global justice that emerged worldwide towards the end of the twentieth century became a privileged social site for building a new emancipatory knowledge. Those social movements that are working towards the construction of alternatives to the dominant capitalist globalization are protagonists in this process. Academic and activist Catherine Walsh argues: "the new forms of thinking are the result of a series of exchanges/learning among several people that take place in situations/sites of poverty/ exclusion. That is, the physical location is the margins of the capitalist space, and the social place is the basement: rural areas or cities' peripheries, or in other words, the weak links in the strings of colonization. To put it in Mignolo's words, the areas of anti-neoliberal concentration" (Walsh, 2004, p.23).

It is in these peripheral locations, society's back alleys, that a slow but continued process of knowledge building is taking place. Both the knowledge produced, i.e. the final product, and the process imply alternatives. The new knowledge comes from practice and becomes praxis (Freire, 1970), i.e. human beings reflect upon the world and act to transform it. Moreover, the new knowledge takes into account current network logics, both for knowledge production and for organizing collective action: cooperation, immediacy, feedback, horizontality, decentralization, flexibility, interconnection and dynamism.

Communication is aimed at transforming and transformation is aimed at communicating (Marí, 2011). Global justice movements understand that it is necessary to overcome the functionalist and behavioral perspective of communication inherited from Mass Communication Research, which directs information and communication processes towards the goals of power centers. In addition, global justice movements are rediscovering the central role of communication in processes of social change, not merely as a topic but also as a transverse axis for their actions, organizations and conceptual schemes.

\section{Epistemology and modernity from the viewpoint of the angel of history}

In the ninth of his Theses on the Philosophy of History (1940), Benjamin (2009) observes Paul Klee's famous painting allegorically: the angel of history gazes at the future critically because "his face is turned towards the past," and this allows him to see the wreckage of the modernizing progress.

Drawn by how Benjamin distances himself from the official version of modernity, the sociologist Sousa Santos (2005) proposes a new theory of history based on two fundamental prerequisites:

- widening the present, so that it can accommodate many of the social experiences currently wasted, marginalized and silenced because they are not in line with the single-minded cultures of the dominant knowledge.

- lessening the future, so that the exaltation of progress is replaced by the search for alternatives that are both utopian and realistic.

The philosopher Zamora (2008, p.85) rereads the allegory of the angel of history as "a critical deciphering of modernity, to be reached not through knowing the totality of the social process, but rather by applying a micro-logical view to the fragments of the world of objects". In Zamora's view, by acknowledging the fragments and remains deposited in the margins of history, it is possible to start rebuilding the process and the social system that caused the destruction in the first place. Likewise, it is possible to incorporate one of the matrices of critical epistemology, namely historian Ginzburg's $(1976,1986)$ evidential paradigm. The evidential methodology starts out from an analysis of small details or traces that may appear insignificant at first, in a semiotic approach to popular culture that takes into account an "epistemology of the particular" (Zubieta, 2000). Such an approach breaks away from the canon's gross mathematical modeling and encyclopedic homogenization. The traces, fragments and remains discarded by the dominant social system, which is unable to subsume them in its logic, hold the potential to become the spark that can set in motion an instrument of critical analysis. 
In order to avoid possible reductionist deviations, e.g. taking refuge in the cultural realm, or a disconnect between micro and macro views, it is useful to link the evidential paradigm with Raymond Williams' concept of the 'residual'. This concept refers to the ability to reappropriate, in the present, mobilizing elements from past emancipatory cultures. By definition, the residual was formed in the past, although it is still active in the cultural process, not merely as an element from the past, but also as an actual component of the present. Thus, certain experiences, meanings and values that cannot be expressed or substantially verified in terms of a dominant culture are nonetheless lived and practiced on the basis of the cultural and social residue of a previous formation.

Through the lenses of the evidential and the residual, the wreckage left behind by progress can become an important part of an alternative political project, less teleological than those forged within the logic of modernity, be they hegemonic or counter-hegemonic, and more attentive to mestizajes ${ }^{2}$ and hybridities.

In this way, the researcher can become the maker of'nocturnal maps'(Martín Barbero, 2002) that reposition communication studies based on the investigation of cultural matrices, social spaces and the communicational operations of the different players. From the perspective of a critical postmodernism, a cartographer must become accustomed to analyzing social processes and cultures as hybrid (García Canclini, 2001). Hybridity, a category alien to the classic, modern world view, is both suitable and necessary for analyzing the current liquid modernity.

In the end, a commitment to mestizaje and hybridity implies taking advantage of the opportunities derived from setting foot in two different cultural camps. The purpose of such diatopical hermeneutics is to "maximize the awareness of the fact that cultures are reciprocally incomplete through dialogue by participating in both cultures, hence its diatopical nature. Diatopical hermeneutics are an exercise in reciprocity among cultures, through which the argumentative premises of one culture are rendered intelligible and credible for the other culture" (Sousa Santos, 2005, p.134). Based on these keys, the academic culture and the activist culture can provide mutual feedback as a strategy for overcoming the distances that, historically, have kept them apart.

\section{Socialization versus commoditization of knowledge}

The intensive process of commoditization of knowledge (Bourdieu, 2003; Mattelart; Neveu, 2003; Sierra Caballero, 2006) seeks to subsume communication research under the logic of commodities, which favors quantitative perspectives. Martín Barbero (2002) criticizes the tendency towards technicist autism and management hegemony that is taking hold of communication studies. Neither the technocentric approach nor the predominant research oriented towards management and commercial matters are particularly sensitive to the cultural and symbolic dimensions of communication, or to its significance for social transformation.

From the beginning, the influence of functionalist and behaviorist tendencies within information and communication theories implied an "economic spell", which directed research towards systems of relationships between empirical elements broken down into variables that could be quantified and formalized (Abril, 1997). The tensions arising from the market and the inherited communication models act in opposition to research concerned with meanings and viewpoints that are alternative to the dominant ones.

In spite of this, the critical perspective referred to in this article is cutting a pathway through the field of information and communication. This process seeks to promote a recursive spiral of shared knowledge based on reflection and a constant search for connections between the empirical world, theory (understood as the production of knowledge) and the conditions in which practice (i.e. the process) takes place (Vizer, 2006).

\section{Knowledge, social transformation and meaning}

The sociologist Vizer (2003, p.117) argues that knowledge is built in order to make sense or give meaning, and that the job of social scientists is to weave symbolic webs of terms with different levels of abstraction and different origins (the academic field, the field of experience, social imagination, cultures, peoples' beliefs).

\footnotetext{
2 The term is used here in the sense attributed to it by Jesús Martín Barbero. The Spanish word is preferred, since 'miscegenation' could be understood in different ways.
} 
The purpose of these symbolic webs is to give meaning to topics and questions that society deems real. The metaphor of the web can become a model for inquiry: human beings are immersed in structural webs that have a significant influence on our possibilities, our moves, our resources and the available alternatives for action. But the web can also be conceived as a symbolic construction of meaning, which we can either observe or participate in as players.

The metaphor of the web becomes a model for inquiry that leads to the search for those vestiges that link the fibers of the material world, making it possible to identify threads of meaning in the midst of apparent chaos and disorder. These webs are woven through the networks of meaning built from theoretical approaches, social institutions and cultural frameworks. Amidst a dense reality, the search for meaning leads to the examination of those informational and communicative devices that go beyond merely technical and instrumental

\section{References}

ABRIL, G. Teoría general de la Información. Madrid: Cátedra, 1997. BENJAMIN, W. On the concept of history. Seattle: CreateSpace, 2009.

BOURDIEU, P. El oficio de científico: ciencia de la ciencia y reflexividad. Barcelona: Anagrama, 2003.

DUSSEL, E. Hacia una filosofía política crítica. Bilbao: Desclée de Brouwer, 2001.

FALS BORDA, O. Acción y conocimiento: como romper el monopolio con investigación-acción participativa. Bogotá: Cinep, 1991.

FREIRE, P. Pedagogía do oprimido. Rio de Janeiro: Paz e Terra, 1970.

GARCÍA CANCLINI, N. Culturas híbridas. Barcelona: Paidós, 2001.

GARCÍA GUTIÉRREZ, A. Desclasificados: pluralismo lógico y violencia de la clasificación. Barcelona: Anthropos, 2007.

GARCÍA GUTIÉRREZ, A. Desclassification in knowledge organization: a post-epistemological essay. Transinformaçao, v.23, n.1, p.5-14, 2011.

GINZBURG, C. El queso y los gusanos. Barcelona: Muchnik, 1976. GINZBURG, C. Mitos, emblemas, indicios. Barcelona: Gedisa, 1986. MARÍ, V.M. Comunicar para transformar, transformar para comunicar. Madrid: Editorial Popular, 2011.

MARTÍN BARBERO, J. Oficio de cartógrafo: travesías latinoamericanas de la comunicación en la cultura. México: Fondo de Cultura Económica, 2002.

MIGNOLO, W. Historias locales/diseños globales: colonialidad, conocimientos subalternos y pensamiento fronterizo. Madrid: Akal, 2003. implementation. Or, in other words, the search for meaning leads to exploration of the social, practical and discursive framework (Abril, 1997) in order to understand what it is that gives direction to the communicational practices of social subjects.

If we follow the advice of communication scholar Martín Barbero (2002), the margins become more than just research themes or objects and instead can be understood as catalysts for reactions that stimulate processes of social change. In this way, the knowledge built by social movements from the margins of the social system can lead to revulsion, i.e. act as a means for healing an internal illness, suggesting new ways of knowledgebuilding.

\section{Acknowledgements}

I am grateful to Florencia Enghel for the translation of this article from Spanish to English.
QUIJANO, A. Colonialidad del poder, globalización y democracia. Lima: Sociedad y Política Ediciones, 2000.

SIERRA CABALLERO, F. Políticas de comunicación y educación. Barcelona: Gedisa, 2006

SODRÉ, M. Antropológica do espelho: uma teoría da comunicaçao linear e em rede. Petrópolis: Vozes, 2002.

SOUSA SANTOS, B. Crítica de la razón indolente: contra el desperdicio de la experiencia. Bilbao: Descleé de Brouwer, 2003.

SOUSA SANTOS, B. El milenio huérfano: ensayos para una nueva cultura política. Madrid: Trotta, 2005.

SOUSA SANTOS, B. Una epistemología del Sur: la reinvención del conocimiento y la emancipación social. Buenos Aires: Siglo XXI, 2009.

VIZER, E. La trama (in)visible de la realidad social: comunicación, sentido, realidad. Buenos Aires: La Crujía Ediciones, 2003.

VIZER, E. Hacia una ecología social y estratégica de la comunicación. Razón y Palabra, n.40, 2006.

WALSH, C. Las geopolíticas del conocimiento y colonialidad del poder. Entrevista a Walter Mignolo. In: WASH, C.; SCHIWY, F.; CASTRO-GÓMEZ, S. (Ed.). Indisciplinar las ciencias sociales: geopolíticas del conocimiento y colonialidad del poder: perspectivas desde lo Andino. Quito: USAB, 2004.

ZAMORA, J.A. Dialéctica mesiánica: tiempo e interrupción en Walter Benjamin. In: AMENGUAL, G.; CABOT, M.; VERMANI, J.L. (Coord.). Ruptura de la tradición: estudios de Walter Benjamin y Martin Heidegger. Madrid: Trotta, 2008.

ZUBIETA, A. (Coord.). Cultura popular y cultura de masas: conceptos, recorridos, polémicas. Buenos Aires: Paidós, 2000. 